\title{
ОРГАНИЗАЦИЯ МЕСТНОГО САМОУПРАВЛЕНИЯ И СОСТОЯНИЕ МЕСТНЫХ БЮДЖЕТОВ ГЕРМАНИИ И РОССИИ: СРАВНИТЕЛЬНЫЙ АНАЛИЗ
}

\author{
Н. Я. Кривоносова \\ Читинский институт (филиал) Байкальского государственного университета, г. Чита, Российская Федерация
}

Информация о статье

Дата поступления

10 ноября 2017 г.

Дата принятия к печати 21 мая 2018 г.

Дата онлайн-размещения 8 июня 2018 г.

\section{Ключевые слова}

Местное самоуправление; территориальная организация; муниципальный бюджет; доходы и расходы бюджета; анализ

\begin{abstract}
Аннотация
Реформирование территориальной организации местного самоуправления РФ и его финансовых основ на протяжении длительного периода входит в число приоритетов экономической политики государства. Практика поступательного движения и развития муниципального хозяйствования характерна и для Германии, поэтому изучение современных тенденций, состояния российского и немецкого местного самоуправления и муниципальных бюджетов последнего десятилетия особенно актуально в современных условиях, характеризующихся высоким уровнем нестабильности во всех странах. В данной статье проанализирована практика территориального реформирования местного самоуправления Германии и России за 2006-2016 гг., выделены общие и специфические особенности такой трансформации, сопоставлены отдельные показатели плотности распределения муниципалитетов обеих стран в целях проверки гипотезы влияния такого реформирования на состояние местных бюджетов. На основе систематизации и аналогии статистических данных общественных фринансов Германии и России периода 2007-2016 гг. был осуществлен анализ динамики доходов, расходов, сбалансированности местных бюджетов обоих государств. Предложен ряд относительных показателей-эквивалентов, на основе которых выполнено сравнение и сделаны выводы о структуре доходов и расходов бюджетов муниципалитетов РФ и ФРГ в условиях территориальной трансформации местного самоуправления. Сделаны выводы лишь о частичном подтверждении указанной гипотезы. Проведенный анализ может быть полезен для дальнейших исследований муниципальных финансов Германии и России с целью определения возможности и целесообразности использования зарубежного опыта в российских условиях.
\end{abstract}

\section{ORGANIZATION OF LOCAL GOVERNMENT AND THE STATE OF LOCAL BUDGETS OF GERMANY AND THE RUSSIAN FEDERATION: COMPARATIVE ANALYSIS}

\author{
Natalia Ya. Krivonosova \\ Chita Institute (Branch) of Baikal State University, Chita, the Russian Federation
}

\section{Article info}

Received

November 10, 2017

Accepted

May 21, 2018

Available online

June 8, 2018

\section{Keywords}

Local self-government; territorial organization; municipal budget;

\begin{abstract}
Realignment of local government's territorial organization and its financial capabilities has for a long time been one of the priorities of the economic policy in the Russian Federation. The practice of progressive advance and municipal infrastructure development is characteristic for Germany as well, thus research study of the current trends, the state of Russian and German local government and the municipal budgets of the last decade is especially important in the current situation, characterized by high level of instability in all countries. The article analyzes the experience of territorial realignment of local government in Germany and the Russian Federation (2006 to 2016), identifies general and specific features of such change, and compares the
\end{abstract}


budget receipts and expenditure; analysis specific series of municipal government density of these countries to test the hypothesis of influence of the realignment on local budgets. The author made the sequence analysis of both countries' local budget receipts, expenditures and sustainability based on taxonomy and similarity of public finances statistics of Germany and the Russian Federation (2007-2016). The author suggested a series of relative index equivalents; on their basis, she made the comparison and conclusions on the Russian Federation and German Federal Republic municipal governments' structure of receipts and expenditure during the realignment of local government. The aforementioned hypothesis is proven only partially true. The analysis data can be useful for further studies on municipal finances of Germany and the Russian Federation in order to determine the feasibility and appropriateness of using foreign experience in Russian conditions.
Период 2007-2016 гг. стал десятилетним рубежом (с учетом переходного периода) практического внедрения и реализации на территории России Федерального закона «О6 общих принципах организации местного самоуправления в Российской Федерации» от 6 октября 2003 г. № 131-Ф3. Такой временной лаг позволяет выявить основные тенденции в развитии территориальной организации местного самоуправления и муниципальных бюджетов России, оценить их текущее состояние, а также сравнить указанные тенденции с происходящими процессами в аналогичном сегменте общественной жизни других стран. Для решения указанной задачи в рамках данной статьи был использован опыт Германии, что объясняется рядом обстоятельств. Во-первых, Германия и Россия как два федеративных государства близки правовыми системами и общностью государственного устройства. Во-вторых, эти страны имеют сходные основные проблемы местного самоуправления - ограниченность финансовых возможностей при решении значительного количества проблем локального характера. И, наконец, третьим аргументом в пользу подобного исследования стала доступность и сопоставимость аналитической базы и фринансовой статистики обеих стран за период 2007-2016 гг.

Современные тенденции организации, развития, преобразования и реформирования местного самоуправления в Российской Федерации нашли свое отражение в работах Е. А. Колодиной [1], С. Н. Леонова [2], В. Н. Лексина [3], Р. В. Бабуна [4], Н. В. Ворошилова [5].

Большой интерес вызывает проблема реализации бюджетных реформ муниципального сектора, а также анализ состояния местных бюджетов России, которым посвящен ряд публикаций Т. В. Сумской [6], А. П. Киреенко и Т. В. Сорокиной [7], Т. В. Файберг [8], Д. В. Дементьева [9].
Вопросы территориального реформирования, особенности фрормирования и использования фринансовых ресурсов местных бюджетов Германии, а также возможности применения накопленного немецкого опыта в российских условиях являлись предметом исследования X. Циммерманна [10], Э. Маркварта [11; 12], Е. М. Бухвальда [13; 14], В. В. Уксусова [15] и др.

Реалии современной российской действительности, а также мировое поступательное движение обусловливают необходимость изучения опыта зарубежных стран в данной предметной области. Кроме того, в условиях нарастания вызовов современной экономики, геополитических и макроэкономических трансформаций последнего десятилетия особенно актуальными становятся анализ и оценка текущего состояния территориальной организации местного самоуправления в ФРГ и РФ, изучение общих тенденций и специфических особенностей территориальной трансформации обеих стран, а также исследование вопросов изменения состояния местных бюджетов в условиях территориального реформирования, что и явилось целью данного исследования.

В настоящее время в Германии и России сложилась двухуровневая система организации местного самоуправления, предполагающая следующие основные типы муниципальных образований (табл. 1).

Таблица 1 Основные типы муниципальных образований Германии и России

\begin{tabular}{|l|l|}
\hline \multicolumn{1}{|c|}{ Deutschland (Германия) } & \multicolumn{1}{|c|}{ Россия } \\
\hline $\begin{array}{l}\text { Kreisfreie Städte («сво- } \\
\text { бодный» город, город } \\
\text { внерайонного подчинения) }\end{array}$ & Городской округ \\
\hline Landkreise (район) & $\begin{array}{l}\text { Муниципальный } \\
\text { район }\end{array}$ \\
\hline $\begin{array}{l}\text { Gemeinden (город и общи- } \\
\text { на районного подчинения) }\end{array}$ & $\begin{array}{l}\text { Городское поселение } \\
\text { Сельское поселение }\end{array}$ \\
\hline
\end{tabular}


За последнее десятилетие количество основных типов муниципальных образований обеих стран изменилось, о чем свидетельствуют данные табл. 2. При этом немецкая практика организации местного самоуправления показывает относительную стабильность в количестве городов внерайонного подчинения (Kreisfreie Städte) и районов (Landkreise) при общей поступательной тенденции снижения количества городов и общин районного подчинения (Gemeinden), российская характеризуется значительным увеличением количества городских округов при одновременном сокращении количества

Современные тенденции уменьшения количества общин, укрупнения муниципалитерные для так называемых новых земель Германии (Бранденбург, Мекленбург - Передняя Померания, Саксония, Саксония-Анхальт, Тюрингия), в качестве обоснования были вызваны рядом причин:

- снижение численности и плотности населения муниципалитетов восточных регионов;

- сложное фринансовое положение восточных федеральных земель, а также муниципалитетов в их составе;

- необходимость сокращения издержек и «удешевление» системы управления на местах.

Подобные тезисы стали основой и для начала процесса территориальных преобразований местного самоуправления в России. В результате общее количество муниципалитетов в обоих государствах значительно сократилось, о чем свидетельствует табл. 2.

Такой относительно небольшой накопленный опыт территориальной трансформации местного самоуправления в Германии иРоссии, как констатируют ряд авторов [5; 12], все-таки поселений и муниципальных районов. тетов, в том числе районного уровня, харак-

дал возможность сфрормулировать некоторые общие тенденции реформирования местного самоуправления для обеих стран:

- изменение территорий не дало в большинстве случаев очевидно значимой экономии и сокращения издержек управления;

- не удалось в краткосрочном периоде повысить экономический потенциал и уровень социально-экономического развития новых образований;

- снизилось качество предоставляемых муниципальных услуг и удовлетворенность жителей муниципальной политикой.

Несмотря на определенную «сходность» основных тенденций и проблем территориального преобразования местного самоуправления в Германии и России, последнее, в свою очередь, имеет некоторые особенности в каждой стране, среди которых прежде всего выделяются территории с особой организацией местного самоуправления.

Для России таковыми являются города федерального значения - Москва, Санкт-Петербург, Севастополь, которые в качестве муниципальных образований имеют внутригородские территории; в Германии города-государства - Берлин, Гамбург и Бремен - в дополнение к полномочиям федеральных земель обладают фуункциями муниципальных образований. Несмотря на «особенность» статуса указанных городов-регионов обоих государств, количество муниципалитетов в них различно и на 31 декабря 2016 г. представлено следующим образом: Берлин - 1, Гамбург - 1, Бремен 21; Москва - 146, Санкт-Петербург - 111,

Verwaltungsgliederung in Deutschlands am 31.12.2016 / Statistisches Bundesamt, Statistisches Jahrbuch, 2017. S. 29. URL: https://www.destatis.de/ DE/Publikationen/StatistischesJahrbuch/Bevoelkerung. pdf?_blob=publicationFile.

Таблица 2

Динамика основных типов муниципальных образований Германии и России за 2006-2016 гг., ед."

\begin{tabular}{|c|r|r|r|r|r|r|}
\hline \multirow{2}{*}{ Период } & \multicolumn{3}{|c|}{ Германия } & \multicolumn{2}{|c|}{ Россия } \\
\cline { 2 - 7 } & $\begin{array}{c}\text { Kreisfreie } \\
\text { Städte }\end{array}$ & Landkreise & Gemeinden & Городской округ & Муниципальный район & Поселения \\
\hline 2006 & 116 & 323 & 12312 & 520 & 1793 & 21658 \\
\hline 2010 & 111 & 301 & 11442 & 515 & 1824 & 20729 \\
\hline 2011 & 107 & 295 & 11292 & 517 & 1821 & 20544 \\
\hline 2012 & 107 & 295 & 11220 & 518 & 1817 & 20409 \\
\hline 2013 & 107 & 295 & 11161 & 520 & 1823 & 20185 \\
\hline 2014 & 107 & 295 & 11116 & 535 & 1788 & 20298 \\
\hline 2015 & 107 & 295 & 11092 & 563 & 1784 & 19769 \\
\hline 2016 & 107 & 294 & 11059 & 567 & 19690 \\
\hline
\end{tabular}

Составлена по данным Statistisches Bundesamt (Федеральное статистическое управление Германии. URL: http://statistischesbundesamt.de) и Федеральной службы государственной статистики России (URL: http://http:// www.gks.ru/free_doc/new_site/bd_munst/munst.htm). Данные приведены по состоянию на 31 декабря соответствующего года. 
Севастополь $-10^{2}$. Тем не менее подобная практика обеих стран в общем и целом не сказывается на качестве оказания муниципальных услуг и удовлетворенности жителей городов-миллионников выполнением обязательств муниципалитетов.

Национальное законодательство Германии предполагает, кроме того, и некоторые другие исключения в организации местного самоуправления. Так, для Германии характерно наличие промежуточной формы муниципальных образований (Regierungsbezirk административный округ). На 31 декабря 2016 г. в Германии насчитывалось 19 подобных объединений, из них в Баден-Вюртемберге - 4, Баварии - 7, Гессене - 3, Северном Рейне - Вестфалии - $5^{3}$, хотя на 31 декабря 2010 г. их численность составляла 22 единицы ${ }^{4}$. Такие административные округа создаются городами и районами для выполнения конкретных задач. Например, в земле Баден-Вюртемберг успешно функционирует «более высокое образование муниципалитетов» - Местная ассоциация (или союз) по делам молодежи и социальной защите Баден-Вюртемберга (Kommunalverband für Jugend und Soziales Baden-Württemberg). Bce 44 района и города земли Баден-Вюртемберг являются членами названного объединения, призванного решать такие вопросы, как поддержка детей и подростков, помощь престарелым и людям с ограниченными возможностями, миграционная политика 5 .

Указанная практика организации и функционирования промежуточной формы муниципальных образований Германии служит примером межмуниципального сотрудничества для купирования наиболее острых и насущных проблем местного сообщества, таких как социальная политика; поддержка малоимущих, безработных, инвалидов; решение вопросов доступности и экологии окружающей среды. При этом подобный опыт межмуниципальных объединений может быть полезен и в российских условиях.

2 Число муниципальных образований по субъектам PD. URL: http://www.gks.ru/free_doc/new_site/bd_ munst/munst.htm.

Verwaltungsgliederung in Deutschlands am 31.12.2016 / Statistisches Bundesamt, Statistisches Jahrbuch, 2017. S. 29.

4 Verwaltungsgliederung in Deutschlands am 31.12.2010 / Statistisches Bundesamt, Statistisches Jahrbuch, 2011. S. 36. URL: https://www.destatis. de /DE / Publikationen / StatistischesJahrbuch / StatistischesJahrbuch2011.pdf?_blob=publicationFile.

${ }^{5}$ Kommunalverband für Jugend und Soziales BadenWürttemberg. URL: https://www.kvjs.de/der-kvjs/ kvjs/\#c16471.
Тем не менее попытки создания отдельных образований на базе существующих муниципалитетов предпринимаются и в России. Речь идет о так называемых территориях опережающего социально-экономического развития в Российской Федерации (ТОР), создаваемых в том числе на базе наукоградов, закрытых административно-территориальных образований, моногородов для привлечения инвестиций, развития экономики, улучшения демографической ситуации и жизни населения. В настоящее время достаточно проблематичным является проведение анализа существующей практики подобных образований России в сравнении с немецким опытом, поскольку процесс создания территорий опережающего развития лишь набирает обороты, решаются некоторые организационные моменты.

Следует подчеркнуть, что в 2014 г. в вопросах территориальной организации местного самоуправления России состоялось еще одно значимое событие - появление двух новых типов муниципальных образований: городского округа с внутригородским делением и внутригородского района. Такое решение в организации местного самоуправления является полной противоположностью тенденции укрупнения муниципалитетов, характерной для современной России и регионов Восточной Германии. Внедрение в практику местного самоуправления данных территориальных единиц, по мнению ряда экспертов, было вызвано необходимостью децентрализации решения вопросов местного значения в крупных административно-территориальных образованиях. Однако на сегодняшний день практика преобразования городских округов в городские округа с внутригородским делением особого распространения не получила [16, с. 68]. Всего можно привести три примера введения городских округов с внутригородским делением - Челябинск', Махачкала7 и Самара ${ }^{8}$. Причиной снижения интереса к такому институту организации местного самоуправления стало, по мнению ряда экспертов Комитета гражданских инициатив, то,

${ }^{6} \mathrm{O}$ статусе Челябинского городского округа и статусе и границах внутригородских районов в составе Челябинского городского округа [Электронный ресурс] : закон Челяб. обл. от 10 июня 2014 г. № 706-3О : (ред. от 18 дек. 2014 г.) / / СПС «КонсультантПлюс».

7 О некоторых вопросах осуществления местного самоуправления в городском округе с внутригородским делением «город Махачкала» и внутригородских муниципальных образованиях в его составе [Электронный ресурс] : закон Респ. Дагестан от 30 июня 2015 г. № 44 / / Там же.

8 Об осуществлении местного самоуправления на территории городского округа Самара Самарской области [Электронный ресурс] : закон Самар. обл. от 30 марта 2015 г. № 23-ГД / / Там же. 
что «основная цель предложенной модели децентрализация власти - не была решена. Увеличение числа депутатского корпуса за счет создания районных советов лишь формально приблизило власть к населению. На практике же районные избранники не обладают достаточными ресурсами для того, чтобы влиять на принятие управленческих решений. Полномочия органов МСУ дублируют функции районных администраций до реформы, а размеры районных бюджетов ненамного превышают сметы районных администраций до реформы». Тем не менее, как считают указанные аналитики, нельзя не учитывать положительный опыт создания городских округов с внутригородским делением при формировании моделей управления городскими агломерациями на базе межмуниципального сотрудничества' .

Таким образом, процесс реформирования территориальной организации местного самоуправления является актуальным вопросом последнего десятилетия не только в Российской Федерации, но и в Федеративной Республике Германии. При этом если для Германии изменение территориальной организации связано лишь с укрупнением и упразднением отдельных территориальных единиц, то в России имеет место, с одной стороны, объединение и укрупнение мелких муниципалитетов на территориях с низкой плотностью населения, а с другой стороны, дробление и внедрение новых институтов местного самоуправления в крупных городах.

В целях проверки гипотезы о влиянии изменения территориальной организации

9 Эксперты КГИ представили доклад «Опыт создания городских округов с внутригородским делением: проблемы и перспективы». URL: https: //komitetgi.ru/ analytics $/ 3158$. местного самоуправления на состояние местных бюджетов обеих стран следует использовать не только абсолютные, но и относительные показатели, отражающие степень обеспеченности страны (плотность распределения) муниципальными образованиями (табл. 3).

Анализ показал, что количество муниципальных образований на 1 млн чел. к концу 2016 г. в Германии составило 139 против 152 в России, что вполне сравнимо, поскольку количество муниципалитетов в России практически в два раза превышает аналогичный показатель в Германии. Однако и численность населения России вдвое больше населения ФРГ. Кроме того, из табл. 3 видно, что сокращение числа муниципалитетов в расчете на 1 млн чел. в обоих государствах за рассматриваемый период происходит равными темпами (для Германии снижение составило 11,51\%, для России - 11,84\%).

Разброс муниципалитетов по территории в обеих странах трудно сопоставить, поскольку в Германии на 1 тыс. км² приходится в среднем 33 муниципалитета, в России - 1 муниципальное образование. Причина - значительная протяженность территории Российской Федерации, а также существенная дифференциация регионов и муниципалитетов России по плотности населения. Для сравнения: средняя плотность населения в Германии ${ }^{10}$ на 31 декабря 2015 г. составила 230 чел. на 1 км², в России ${ }^{11}-8,6$ чел. на 1 км².

${ }^{10}$ Gebiet und Bevölkerung — Fläche und Bevölkerung. Statistisches Ämter. Des Bundes und der Länder. URL: http://www.statistik-portal.de/Statistik-Portal/de_ jb01_jahrtab1.asp.

11 Российский статистический ежегодник. 2016 : стат. сб. / Росстат. М., 2016. С. 35.

Таблица 3

Динамика плотности распределения муниципалитетов в Германии и России в 2006-2016 гг.

\begin{tabular}{|c|c|c|c|c|c|c|c|c|c|c|}
\hline \multirow[t]{2}{*}{ Период } & \multicolumn{2}{|c|}{$\begin{array}{c}\text { Число } \\
\text { муниципальных } \\
\text { образований, всего }\end{array}$} & \multicolumn{2}{|c|}{$\begin{array}{c}\text { Численность } \\
\text { населения, } \\
\text { млн чел. }\end{array}$} & \multicolumn{2}{|c|}{$\begin{array}{c}\text { Площадь } \\
\text { территории, } \\
\text { тыс. км² }\end{array}$} & \multicolumn{2}{|c|}{$\begin{array}{c}\text { Число } \\
\text { муниципальных } \\
\text { образований } \\
\text { в расчете } \\
\text { на } 1 \text { млн чел. }\end{array}$} & \multicolumn{2}{|c|}{$\begin{array}{c}\text { Число } \\
\text { муниципальных } \\
\text { образований } \\
\text { в расчете } \\
\text { на } 1 \text { тыс. км² }\end{array}$} \\
\hline & Германия & Россия & Германия & Россия & Германия & Россия & Германия & Россия & Германия & Россия \\
\hline 2006 & 12770 & 24207 & 82,3 & 142,8 & \multirow{8}{*}{357,0} & \multirow{5}{*}{17098,2} & 155 & 170 & 35,8 & 1,4 \\
\hline 2010 & 11876 & 23304 & 81,7 & 142,9 & & & 145 & 163 & 33,3 & 1,4 \\
\hline 2011 & 11713 & 23118 & 80,3 & 143,0 & & & 146 & 162 & 32,8 & 1,4 \\
\hline 2012 & 11641 & 23001 & 80,5 & 143,3 & & & 145 & 161 & 32,6 & 1,3 \\
\hline 2013 & 11582 & 22777 & 80,8 & 143,7 & & & 143 & 159 & 32,4 & 1,3 \\
\hline 2014 & 11537 & 22923 & 81,2 & 146,3 & & \multirow{3}{*}{17125,2} & 142 & 157 & 32,3 & 1,3 \\
\hline 2015 & 11513 & 22406 & 82,2 & 146,5 & & & 140 & 153 & 32,2 & 1,3 \\
\hline 2016 & 11479 & 22327 & 82,3 & 146,8 & & & 139 & 152 & 32,1 & 1,3 \\
\hline
\end{tabular}

" Рассчитано на 31 декабря соответствующего года для Германии на основании Statistisches Jahrbuch (за 20112017 гг.); для России — Российского статистического ежегодника (за 2007-2016 гг.). 
Тем не менее показательной является динамика сокращения числа муниципалитетов в расчете на 1 тыс. км². Так, для ФРГ на начало анализируемого периода плотность распределения муниципальных образований составляла практически 36 единиц на 1 тыс. км², а на 2016 г. - 32 единицы. Российская же трансформация, несмотря на значительные абсолютные изменения в территориальной организации, носит устойчивый характер - количество муниципалитетов на 1 тыс. км² сохраняется в пределах одной единицы.

Таким образом, проведенный анализ показал, что реформирование местного самоуправления в Германии происходит при одновременном укрупнении муниципалитетов как с точки зрения численности населения, так ис точки зрения пространственного аспекта. В России территориальные преобразования местного самоуправления характеризуются сохранением обеспеченности по территориальному признаку при уплотнении муниципалитетов по численности. Указанные обстоятельства и выявленные тенденции можно сопоставить с текущим состоянием и динамикой развития муниципальных финансов обеих стран.
Для оценки их состояния и осуществления анализа рассмотрим основные параметры местных бюджетов Германии и России в соответствии с требованиями национального законодательства за период 2007-2016 гг.

Следует отметить, что статистика общественных финансов Германии, несмотря на то что объединение страны состоялось в 1990 г., до сих пор представлена отдельно по так называемым старым землям («alte Länder») и новым землям («neue Länder»). Однако для целей настоящего исследования показатели функционирования местных бюджетов были систематизированы и сгруппированы в целом для страны, тем не менее, в анализе будут использованы данные по восточным землям, для которых наиболее актуальны вопросы территориального изменения.

Доходы и расходы местных бюджетов Германии в соответствии с требованиями норм бюджетного права представлены совокупностью двух бюджетов - административного и имущественного. Динамика доходов местных бюджетов ФРГ за 2007-2016 гг. отражена в табл. 4.

Таблица 4

Доходы местных бюджетов Германии за 2007-2016 гг., млрд евро

\begin{tabular}{|c|c|c|c|c|c|c|c|c|c|c|}
\hline Показатель & 2007 & 2008 & 2009 & 2010 & 2011 & 2012 & 2013 & 2014 & 2015 & 2016 \\
\hline $\begin{array}{l}\text { Доходы административного } \\
\text { бюджета }\end{array}$ & 153,5 & 161,1 & 155,0 & 157,3 & 166,6 & 175,2 & 184,1 & 191,1 & 203,1 & 218,0 \\
\hline $\begin{array}{l}\text { В том числе: } \\
\text { "alte Länder» }\end{array}$ & 130,0 & 136,0 & 130,1 & 132,7 & 140,9 & 149,3 & 156,6 & 162,9 & 174,1 & 187,1 \\
\hline «neue Länder» & 23,5 & 25,1 & 24,9 & 24,6 & 25,7 & 25,9 & 27,5 & 28,2 & 29,0 & 30,9 \\
\hline Налоговые доходы & 66,1 & 70,6 & 62,2 & 63,8 & 69,8 & 74,3 & 76,9 & 79,5 & 84,8 & 89,7 \\
\hline $\begin{array}{l}\text { Промысловый налог } \\
\text { (Gewerbesteuer) }\end{array}$ & 30,0 & 31,4 & 25,0 & 26,9 & 30,5 & 32,3 & 32,6 & 33,1 & 34,8 & 38,3 \\
\hline $\begin{array}{l}\text { Подоходный налог } \\
\text { (Gemeindeanteil an der ESt) }\end{array}$ & 22,9 & 25,9 & 23,7 & 23,0 & 24,6 & 26,8 & 28,5 & 30,3 & 32,5 & 33,5 \\
\hline $\begin{array}{l}\text { Налог с оборота или НДС } \\
\text { (Gemeindeanteil an der USt) }\end{array}$ & 3,1 & 3,2 & 3,2 & 3,3 & 3,5 & 3,6 & 3,6 & 3,7 & 4,3 & 4,4 \\
\hline $\begin{array}{l}\text { Поземельный налог } \\
\text { (Grundsteuern) }\end{array}$ & 9,4 & 9,5 & 9,6 & 10,0 & 10,3 & 10,6 & 11,1 & 11,3 & 11,8 & 12,3 \\
\hline Другие налоги & 0,7 & 0,6 & 0,7 & 0,6 & 0,9 & 1,0 & 1,1 & 1,1 & 1,4 & 1,2 \\
\hline $\begin{array}{l}\text { Перечисления от земель } \\
\text { (регионов) }\end{array}$ & 49,1 & 52,4 & 53,6 & 53,6 & 56,6 & 60,0 & 65,0 & 68,8 & 74,8 & 83,4 \\
\hline Общего назначения & 32,6 & 35,2 & 35,6 & 34,4 & 35,5 & 37,1 & 39,6 & 42,0 & 42,9 & 45,9 \\
\hline Целевого назначения & 16,5 & 17,2 & 18,0 & 19,2 & 21,1 & 22,9 & 25,4 & 26,8 & 31,9 & 37,5 \\
\hline Сборы (пошлины) & 16,1 & 15,9 & 15,8 & 16,2 & 16,5 & 16,7 & 17,1 & 17,3 & 17,9 & 18,9 \\
\hline Прочие поступления & 22,2 & 22,2 & 23,4 & 23,7 & 23,7 & 24,2 & 25,1 & 25,5 & 25,6 & 26,0 \\
\hline $\begin{array}{l}\text { Доходы имущественного } \\
\text { бюджета }\end{array}$ & 16,2 & 15,5 & 15,8 & 17,9 & 17,5 & 14,9 & 15,2 & 15,3 & 16,0 & 15,6 \\
\hline $\begin{array}{l}\text { В том числе: } \\
\text { «alte Länder» }\end{array}$ & 12,3 & 11,6 & 11,9 & 13,8 & 13,8 & 12,0 & 12,3 & 12,2 & 12,6 & 12,5 \\
\hline «neue Länder» & 3,9 & 3,9 & 3,9 & 4,1 & 3,7 & 2,9 & 2,9 & 3,1 & 3,4 & 3,1 \\
\hline $\begin{array}{l}\text { Доходы от продажи имуще- } \\
\text { ства иучастия } \\
\text { в капитале }\end{array}$ & 1,2 & 0,6 & 0,5 & 1,0 & 0,6 & 0,7 & 0,8 & 1,0 & 0,8 & 0,8 \\
\hline
\end{tabular}




\begin{tabular}{|l|r|r|r|r|r|r|r|r|r|r|}
\hline \multicolumn{1}{|c|}{ Показатель } & 2007 & 2008 & 2009 & 2010 & 2011 & 2012 & 2013 & 2014 & 2015 & 2016 \\
\hline $\begin{array}{l}\text { Доходы от продажи нефинан- } \\
\text { совых активов }\end{array}$ & 3,9 & 3,7 & 3,2 & 3,6 & 4,0 & 3,9 & 3,9 & 3,9 & 4,2 & 4,3 \\
\hline Доходы от продажи земли & 3,7 & 3,5 & 3,0 & 3,4 & 3,7 & 3,7 & 3,7 & 3,8 & 4,0 & 4,1 \\
\hline $\begin{array}{l}\text { Доходы от продажи другого } \\
\text { имущества }\end{array}$ & 0,2 & 0,2 & 0,2 & 0,2 & 0,3 & 0,2 & 0,2 & 0,1 & 0,2 & 0,2 \\
\hline $\begin{array}{l}\text { Вклады } \\
\text { Инвестиционные ассигнова- } \\
\text { ния от земель (регионов) }\end{array}$ & 1,5 & 1,4 & 1,3 & 1,3 & 1,4 & 1,4 & 1,4 & 1,4 & 1,5 & 1,5 \\
\hline $\begin{array}{l}\text { Прочие имущественные } \\
\text { поступления }\end{array}$ & 1,9 & 1,9 & 2,5 & 2,3 & 2,3 & 1,9 & 1,9 & 1,7 & 2,1 & 2,2 \\
\hline $\begin{array}{l}\text { Всего (доходы администра- } \\
\text { тивного бюджета + доходы } \\
\text { имущественного бюджета) }\end{array}$ & $\mathbf{1 6 9 , 7}$ & $\mathbf{1 7 6 , 6}$ & $\mathbf{1 7 0 , 8}$ & $\mathbf{1 7 5 , 2}$ & $\mathbf{1 8 4 , 1}$ & $\mathbf{1 9 0 , 1}$ & $\mathbf{1 9 9 , 3}$ & $\mathbf{2 0 6 , 4}$ & $\mathbf{2 1 9 , 1}$ & $\mathbf{2 3 3 , 6}$ \\
\hline $\begin{array}{l}\text { В том числе: } \\
\text { «аlте Ländег» }\end{array}$ & $\mathbf{1 4 2 , 3}$ & $\mathbf{1 4 7 , 6}$ & $\mathbf{1 4 2 , 0}$ & $\mathbf{1 4 6 , 5}$ & $\mathbf{1 5 4 , 7}$ & $\mathbf{1 6 1 , 3}$ & $\mathbf{1 6 8 , 9}$ & $\mathbf{1 7 5 , 1}$ & $\mathbf{1 8 6 , 7}$ & $\mathbf{1 9 9 , 6}$ \\
\hline $\begin{array}{l}\text { «nеuе Länder» } \\
\text { 'Рассчитано на, }\end{array}$ & $\mathbf{2 7 , 4}$ & $\mathbf{2 9 , 0}$ & $\mathbf{2 8 , 8}$ & $\mathbf{2 8 , 7}$ & $\mathbf{2 9 , 4}$ & $\mathbf{2 8 , 8}$ & $\mathbf{3 0 , 4}$ & $\mathbf{3 1 , 3}$ & $\mathbf{3 2 , 4}$ & $\mathbf{3 4 , 0}$ \\
\hline
\end{tabular}

Рассчитано на 31 декабря соответствующего года на основании Eckdaten zur Entwicklung und Struktur der Kommunalfinanzen 2007 bis 2016. URL: http://www.bundesfinanzministerium.de/SiteGlobals/Forms/Suche/ Servicesuche Formular.html?showFacetDocType=true\&input_ $=15980 \&$ resourceld $=5968 \&$ submit. $x=0 \&$ submit. $y=0 \& l a n g=$ de\&templateQueryString=kommunalfinanzen\&baseDocType=Audio+Basepage+CallForBids+Event+GCJournal+GCPrese ntation+Interview+JobOffer+Law+News+PBBook+PBHandout+PressRelease+Publication+Speech+Video+Vita\&showFa cetCategoryThemen $=$ true\&pageLocale $=$ de.

Как показывает анализ табл. 4, на протяжении всего рассматриваемого периода в целом наблюдается рост доходов местных бюджетов Германии. Исключением являются лишь 2009-2010 гг., когда снижение поступлений по промысловому, подоходному налогам, а также отдельным показателям имущественного бюджета (прототипа российских неналоговых доходов) отразилось на общем уменьшении доходов бюджетов муниципалитетов ФРГ. Несмотря на такое эпизодическое сокращение доходов местных бюджетов
Германии периода 2009-2010 гг., которое можно объяснить последствиями мирового финансового кризиса (снижение совокупных доходов предпринимателей и физических лиц), расходы местных бюджетов за анализируемый период увеличились с 161,6 до 229,3 млрд евро (табл. 5). Однако, как показал анализ, изменение доходов местных бюджетов ФРГ обусловлено в первую очередь колебаниями доходов лишь по так называемым старым землям, при этом отклонения доходов местных бюджетов восточных земель незначительны.

Расходы местных бюджетов Германии за 2007-2016 гг., млрд евро

\begin{tabular}{|l|r|r|r|r|r|r|r|r|r|r|}
\hline \multicolumn{1}{|c|}{ Показатель } & 2007 & 2008 & 2009 & 2010 & 2011 & 2012 & 2013 & 2014 & 2015 & 2016 \\
\hline Расходы административного бюджета & $\mathbf{1 3 6 , 8}$ & $\mathbf{1 4 3 , 0}$ & $\mathbf{1 4 8 , 7}$ & $\mathbf{1 5 3 , 7}$ & $\mathbf{1 5 7 , 3}$ & $\mathbf{1 6 2 , 2}$ & $\mathbf{1 7 0 , 9}$ & $\mathbf{1 7 7 , 8}$ & $\mathbf{1 8 7 , 3}$ & $\mathbf{1 9 9 , 0}$ \\
\hline $\begin{array}{l}\text { В том числе: } \\
\text { «alte Länder» }\end{array}$ & $\mathbf{1 1 5 , 3}$ & $\mathbf{1 2 0 , 8}$ & $\mathbf{1 2 5 , 6}$ & $\mathbf{1 3 0 , 4}$ & $\mathbf{1 3 3 , 2}$ & $\mathbf{1 3 7 , 5}$ & $\mathbf{1 4 4 , 9}$ & $\mathbf{1 5 1 , 0}$ & $\mathbf{1 5 9 , 6}$ & $\mathbf{1 6 9 , 9}$ \\
\hline «neue Länder» & $\mathbf{2 1 , 5}$ & $\mathbf{2 2 , 2}$ & $\mathbf{2 3 , 1}$ & $\mathbf{2 3 , 3}$ & $\mathbf{2 4 , 1}$ & $\mathbf{2 4 , 7}$ & $\mathbf{2 6 , 0}$ & $\mathbf{2 6 , 8}$ & $\mathbf{2 7 , 7}$ & $\mathbf{2 9 , 1}$ \\
\hline $\begin{array}{l}\text { Расходы на персонал (расходы } \\
\text { на оплату труда и социальное } \\
\text { страхование) }\end{array}$ & 40,6 & 42,4 & 44,4 & 45,1 & 46,5 & 48,2 & 50,3 & 52,4 & 54,1 & 56,7 \\
\hline $\begin{array}{l}\text { Текущие расходы (содержание } \\
\text { зданий, сооружений, техники и } \\
\text { другие хозяйственные расходы) }\end{array}$ & 33,2 & 35,5 & 36,7 & 38,6 & 39,1 & 39,7 & 42,3 & 44,2 & 46,1 & 48,3 \\
\hline Расходы на уплату процентов & 5,2 & 5,3 & 4,5 & 4,3 & 4,2 & 4,0 & 3,8 & 3,5 & 3,3 & 3,0 \\
\hline $\begin{array}{l}\text { Текущие ассигнования и гранты } \\
\text { (перечисления) }\end{array}$ & 16,0 & 17,2 & 18,2 & 19,1 & 19,9 & 20,6 & 22,3 & 23,1 & 24,9 & 25,8 \\
\hline Расходы на социальные услуги & 37,9 & 38,6 & 40,5 & 41,9 & 43,0 & 44,7 & 47,2 & 49,2 & 53,4 & 59,1 \\
\hline Другие расходы & 3,9 & 4,0 & 4,4 & 4,7 & 4,6 & 5,0 & 5,0 & 5,4 & 5,5 & 6,1 \\
\hline Расходы имущественного бюджета & $\mathbf{2 4 , 8}$ & $\mathbf{2 5 , 0}$ & $\mathbf{2 9 , 5}$ & $\mathbf{2 8 , 6}$ & $\mathbf{2 7 , 6}$ & $\mathbf{2 5 , 3}$ & $\mathbf{2 6 , 7}$ & $\mathbf{2 7 , 5}$ & $\mathbf{2 8 , 2}$ & $\mathbf{3 0 , 1}$ \\
\hline $\begin{array}{l}\text { В том числе: } \\
\text { «аІте Lӓпдег» }\end{array}$ & $\mathbf{2 0 , 2}$ & $\mathbf{2 0 , 5}$ & $\mathbf{2 4 , 6}$ & $\mathbf{2 3 , 5}$ & $\mathbf{2 2 , 9}$ & $\mathbf{2 1 , 3}$ & $\mathbf{2 3 , 0}$ & $\mathbf{2 3 , 6}$ & $\mathbf{2 4 , 3}$ & $\mathbf{2 6 , 2}$ \\
\hline
\end{tabular}


Окончание табл. 5

\begin{tabular}{|c|c|c|c|c|c|c|c|c|c|c|}
\hline Показатель & 2007 & 2008 & 2009 & 2010 & 2011 & 2012 & 2013 & 2014 & 2015 & 2016 \\
\hline «neue Länder» & 4,6 & 4,5 & 4,9 & 5,1 & 4,7 & 4,0 & 3,7 & 3,9 & 3,9 & 3,9 \\
\hline $\begin{array}{l}\text { Расходы на инвестиции, капиталь- } \\
\text { ные вложения }\end{array}$ & 1,1 & 1,1 & 3,7 & 1,6 & 1,7 & 1,8 & 1,9 & 2,0 & 2,4 & 2,2 \\
\hline $\begin{array}{l}\text { Расходы на приобретение нефинан- } \\
\text { совых активов }\end{array}$ & 4,5 & 4,8 & 5,0 & 4,6 & 4,4 & 4,3 & 4,8 & 5,2 & 5,8 & 6,2 \\
\hline Расходы на приобретение земли & 2,6 & 2,9 & 2,5 & 2,2 & 2,1 & 2,2 & 2,4 & 2,6 & 3,2 & 3,3 \\
\hline $\begin{array}{l}\text { Расходы на приобретение прочих } \\
\text { нефинансовых активов }\end{array}$ & 1,9 & 1,9 & 2,5 & 2,4 & 2,3 & 2,1 & 2,4 & 2,6 & 2,6 & 2,9 \\
\hline Расходы на строительство & 15,5 & 15,8 & 16,8 & 18,6 & 17,7 & 15,3 & 16,0 & 16,9 & 16,2 & 17,6 \\
\hline $\begin{array}{l}\text { Расходы на стимулирование } \\
\text { инвестиций }\end{array}$ & 2,8 & 2,4 & 2,5 & 2,7 & 2,8 & 2,3 & 2,6 & 2,3 & 2,3 & 2,2 \\
\hline Другие расходы & 0,9 & 0,9 & 1,5 & 1,1 & 1,0 & 1,6 & 1,4 & 1,1 & 1,5 & 1,9 \\
\hline $\begin{array}{l}\text { Всего (расходы административного } \\
\text { бюджета + расходы имущественно- } \\
\text { го бюджета) }\end{array}$ & 161,6 & 168,0 & 178,2 & 182,3 & 184,9 & 187,5 & 197,6 & 205,3 & 215,5 & 229,1 \\
\hline $\begin{array}{l}\text { В том числе: } \\
\text { "alte Länder» }\end{array}$ & 135,5 & 141,3 & 150,2 & 153,9 & 156,1 & 158,8 & 167,9 & 174,6 & 183,9 & 196,1 \\
\hline «neue Länder» & 26,1 & 26,7 & 28,0 & 28,4 & 28,8 & 28,7 & 29,7 & 30,7 & 31,6 & 33,0 \\
\hline $\begin{array}{l}\text { "Рассчитано на } 31 \text { декабря соотве } \\
\text { Kommunalfinanzen } 2007 \text { bis } 2016 \text {. URL: http: } \\
\text { Formular.html?showFacetDocType=true\&in } \\
\text { eryString=kommunalfinanzen\&baseDocTyp } \\
\text { +JobOffer+Law+News+PBBook+PBHando } \\
\text { n=true\&pageLocale=de. }\end{array}$ & вующе & его год & а на о & сновании & n Eckda & ten zur & Entwicl & lung ur & nd Struk & $\begin{array}{l}\text { tur der } \\
\text { esuche } \\
\text { plateQu } \\
\text { terview }\end{array}$ \\
\hline
\end{tabular}

Расходы местных бюджетов ФРГ, как видно из табл. 5, также имеют устойчивую тенденцию к росту за анализируемый период. При этом наибольший рост расходов наблюдается по так называемым старым землям. Местные бюджеты восточных земель характеризуются незначительным увеличением административного бюджета при тенденции к сокращению расходов на инвестиции, капитальные вложения, строительство и приобретение нефинансовых активов, что говорит о тенденции уменьшения бюджета развития. Подобные тенденции сокращения расходов на инвестиционные цели характерны и для местных бюджетов России, что обусловлено незначительным объемом их доходов.

Доходы местных бюджетов России в соответствии с Бюджетным кодексом РФ формируются за счет налоговых, неналоговых и безвозмездных поступлений. Их состав, размер, динамика для бюджетов муниципального уровня России за 2007-2016 гг. представлены в табл. 6.

Доходы местных бюджетов России за 2007-2016 гг., млрд р.'

Таблица 6

\begin{tabular}{|l|r|r|r|r|r|r|r|r|r|r|}
\hline \multicolumn{1}{|c|}{ Показатель } & \multicolumn{1}{|c|}{2007} & \multicolumn{1}{c|}{2008} & \multicolumn{1}{c|}{2009} & \multicolumn{1}{|c|}{2010} & 2011 & 2012 & 2013 & 2014 & 2015 & 2016 \\
\hline Налоговые доходы & 579,5 & 720,4 & 719,8 & 806,8 & 879,0 & 935,8 & 1042,7 & 969,3 & 999,3 & 1053,6 \\
\hline НДсл & 388,7 & 494,1 & 494,6 & 525,2 & 583,5 & 656,7 & 729,0 & 615,8 & 617,1 & 660,5 \\
\hline $\begin{array}{l}\text { Налог на имущество } \\
\text { физических лиц }\end{array}$ & 6,8 & 8,9 & 14,2 & 13,5 & 4,4 & 15,8 & 19,8 & 23,2 & 25,7 & 28,9 \\
\hline Земельный налог & 63,9 & 73,8 & 88,3 & 102,4 & 107,1 & 124,9 & 137,8 & 155,3 & 163,8 & 156,4 \\
\hline ЕНВД & 48,9 & 54,9 & 56,1 & 62,1 & 68,3 & 76,9 & 72,8 & 75,2 & 77,0 & 72,8 \\
\hline ЕСХН & 1,1 & 1,8 & 1,7 & 2 & 3,1 & 3,3 & 4,0 & 4,7 & 7,4 & 11,3 \\
\hline Налог по патенту & - & - & - & - & - & - & 1,5 & 2,3 & 3,4 & 4,5 \\
\hline $\begin{array}{l}\text { Акцизы } \\
\text { на нефтепродукты }\end{array}$ & - & - & - & - & - & - & - & 24,7 & 27,8 & 39,7 \\
\hline Другие налоги & 70,1 & 86,9 & 64,9 & 101,6 & 110,6 & 58,2 & 77,8 & 68,1 & 77,1 & 79,5 \\
\hline Неналоговые доходы & 239,7 & 278,6 & 243,5 & 253,1 & 279,0 & 264,0 & 275,0 & 301,4 & 279,1 & 277,5 \\
\hline $\begin{array}{l}\text { Доходы от пред- } \\
\text { принимательской } \\
\text { деятельности }\end{array}$ & 45,5 & 29,8 & 18,7 & 7,7 & - & - & - & - & - & - \\
\hline $\begin{array}{l}\text { Доходы от использо- } \\
\text { вания имущества }\end{array}$ & 107,5 & 129,4 & 118,8 & 125,1 & 130,1 & 139,3 & 150,1 & 173,4 & 158,2 & 155,8 \\
\hline
\end{tabular}


Окончание табл. 6

\begin{tabular}{|c|c|c|c|c|c|c|c|c|c|c|}
\hline Показатель & 2007 & 2008 & 2009 & 2010 & 2011 & 2012 & 2013 & 2014 & 2015 & 2016 \\
\hline $\begin{array}{l}\text { Платежи за пользо- } \\
\text { вание природными } \\
\text { ресурсами }\end{array}$ & 6,5 & $\cdots$ & 7,1 & 7,9 & 8,5 & 11,3 & 11,9 & 10,6 & 10,3 & 11,8 \\
\hline $\begin{array}{l}\text { Доходы от платных } \\
\text { услуг }\end{array}$ & 7,8 & $\cdots$ & 30,6 & 38,6 & 40,5 & 15,7 & 16,8 & 17,1 & 20,2 & 22,9 \\
\hline $\begin{array}{l}\text { Доходы от продажи } \\
\text { материальных и } \\
\text { нематериальных } \\
\text { активов }\end{array}$ & 48,6 & 67,4 & 49,8 & 57,1 & 69,6 & 72,1 & 69,7 & 74,7 & 61,5 & 56,2 \\
\hline Штрафры, санкции & 12,52 & $\ldots$ & 16,7 & \multirow[b]{2}{*}{16,7} & \multirow[b]{2}{*}{30,3} & \multirow[b]{2}{*}{25,6} & \multirow[b]{2}{*}{26,5} & \multirow[b]{2}{*}{25,6} & \multirow[b]{2}{*}{28,9} & \multirow[b]{2}{*}{30,8} \\
\hline $\begin{array}{l}\text { Другие неналоговые } \\
\text { доходы }\end{array}$ & 11,28 & $\cdots$ & 1,8 & & & & & & & \\
\hline $\begin{array}{l}\text { Безвозмездные } \\
\text { поступления }\end{array}$ & 1129,6 & 1412,7 & 1424,7 & 1540,6 & 1798,2 & 1938,6 & 2069,0 & 2238,0 & 2216,2 & 2309,3 \\
\hline Субвенции & 561,6 & 531,6 & 582,7 & 627,2 & 711,4 & 893,6 & 943,8 & 1203,5 & 1238,7 & 1293,1 \\
\hline Дотации & 271,4 & 337,2 & 302,1 & 327,5 & 393,0 & 308,6 & 314,6 & 283,0 & 303,0 & 324,2 \\
\hline Субсидии & 264,9 & 438,7 & 418,7 & 455,1 & 527,1 & 592,2 & 666,2 & 607,2 & 526,7 & 533,9 \\
\hline Иные трансферты & 31,7 & 105,2 & 121,2 & 130,8 & 166,7 & 144,2 & 144,4 & 144,3 & 147,8 & 158,1 \\
\hline Всего & 1948,8 & 2411,6 & 2388,0 & 2600,5 & 2961,1 & 3138,4 & 3386,7 & 3508,7 & 3497,1 & 3645,1 \\
\hline
\end{tabular}

"Рассчитано на 31 декабря соответствующего года на основании данных Министерства финансов РФ (Результаты мониторинга местных бюджетов за период 2007-2016 гг. URL: https://www.minfin.ru/ru/perfomance/regions/ monitoring_results/Monitoring_local/results).

Анализ табл. 6 показал, что на протяжении всего анализируемого периода доходы местных бюджетов РФ в среднем ежегодно увеличивались по отношению к предыдущему году на 7 \%. Лишь в 2015 г. общая сумма доходов местных бюджетов уменьшилась до 3 497,1 млрд р. против 3 508,7 млрд р. в 2014 г. Такая тенденция полностью соответствует динамике роста безвозмездных поступлений, перечисляемых в местные бюджеты с регионального уровня, что говорит о значительной финансовой зависимости бюджетов муниципальных образований России и неспособности последних наращивать фринансирование инвестиционных расходов.

Расходы местных бюджетов Рф группируются в соответствии с бюджетной классификацией по разделам. Их состав и размер для местных бюджетов РФ за 2007-2016 гг. представлен в табл. 7.

Анализ табл. 7 показал, что, несмотря на эпизодическое сокращение совокупных доходов или отдельных видов доходов в отдельные финансовые годы рассматриваемого периода, расходы местных бюджетов России в 2007-2016 гг. имели устойчивую тенденцию к постоянному росту. Причиной является значительное количество вопросов местного значения, а также государственных полномочий, переданных на муниципальный уровень.

Указанное увеличение расходов местных бюджетов обеих стран следует сопоставить с аналогичными показателями доходов таких бюджетов, что позволит выявить их сбалансированность (табл. 8).

Таблица 7

Расходы местных бюджетов России за 2007-2016 гг., млрд р.

\begin{tabular}{|l|r|r|r|r|r|r|r|r|r|r|}
\hline \multicolumn{1}{|c|}{ Показатель } & \multicolumn{1}{c|}{2007} & \multicolumn{1}{c|}{2008} & \multicolumn{1}{c|}{2009} & 2010 & 2011 & 2012 & \multicolumn{1}{c|}{2013} & 2014 & 2015 & 2016 \\
\hline Управление & 174,6 & 213,1 & 213,6 & 232,8 & 253,0 & 285,6 & 307,2 & 321,2 & 334,2 & 338,2 \\
\hline ЖКХ & 364,3 & 482,4 & 447,2 & 478,7 & 555,0 & 475,7 & 481,1 & 504,2 & 461,5 & 459,8 \\
\hline Образование & 673,6 & 840,5 & 886,3 & 935,6 & 1118,1 & 1310,5 & 1570,3 & 1677,8 & 1714,7 & 1760,4 \\
\hline Культура & 77,2 & 95,0 & 95,1 & 103,9 & 127,1 & 143,4 & 162,4 & 186,7 & 188,4 & 195 \\
\hline Физическая культура & - & - & - & - & - & - & 58,5 & 64,0 & 62,8 & 60,1 \\
\hline Здравоохранение* & 255,8 & 300,4 & 278,7 & 284,7 & 298,3 & 170,5 & 60,2 & - & 18,3 & 14,6 \\
\hline Социальная политика & 155,4 & 174,4 & 191,9 & 240,6 & 257,1 & 275,7 & 307,2 & 321,2 & 291,2 & 293,8 \\
\hline Прочие расходы & 232,9 & 316,4 & 327,5 & 336,1 & 367,2 & 504,5 & 481,9 & 456,5 & 489,3 & 533,2 \\
\hline \multicolumn{1}{|c|}{ Всего расходов } & 1933,8 & 2422,2 & 2440,3 & 2612,4 & 2975,8 & 3165,9 & 3428,9 & 3563,4 & 3560,4 & 3655,1 \\
\hline
\end{tabular}

"Рассчитано на 31 декабря соответствующего года на основании данных Министерства финансов РФ (Результаты мониторинга местных бюджетов за период 2007-2016 гг. URL: https://www.minfin.ru/ru/perfomance/regions/ monitoring_results/Monitoring_local/results).

До 2011 г. раздел «Здравоохранение» есть раздел «Здравоохранение и спорт». 
Сбалансированность местных бюджетов Германии и России в 2007-2016 гг.

\begin{tabular}{|c|c|c|c|c|c|c|c|c|c|c|c|}
\hline \multicolumn{2}{|c|}{ Показатель } & 2007 & 2008 & 2009 & 2010 & 2011 & 2012 & 2013 & 2014 & 2015 & 2016 \\
\hline \multirow{3}{*}{$\begin{array}{l}\text { Германия, } \\
\text { млрд евро }\end{array}$} & $\begin{array}{l}\text { Итого } \\
\text { доходы }\end{array}$ & 169,7 & 176,6 & 170,8 & 175,4 & 184,1 & 190,1 & 199,3 & 206,4 & 219,1 & 233,6 \\
\hline & $\begin{array}{l}\text { Итого } \\
\text { расходы }\end{array}$ & 161,6 & 168,0 & 178,2 & 182,3 & 184,9 & 187,5 & 197,6 & 205,3 & 215,5 & 229,3 \\
\hline & $\begin{array}{l}\text { Дефицит } \\
(-) \\
\text { Профиицит } \\
(+)\end{array}$ & 8,1 & 8,6 & $-7,4$ & $-6,9$ & $-0,8$ & 2,6 & 1,7 & 1,1 & 3,6 & 4,3 \\
\hline \multirow{3}{*}{$\begin{array}{l}\text { Россия, } \\
\text { млрд р. }\end{array}$} & $\begin{array}{l}\text { Итого } \\
\text { доходы }\end{array}$ & 1948,8 & 2411,6 & 2388,0 & 2600,5 & 2961,1 & 3138,4 & 3386,7 & 3508,7 & 3497,1 & 3645,1 \\
\hline & $\begin{array}{l}\text { Итого } \\
\text { расходы }\end{array}$ & 1933,8 & 2422,2 & 2440,3 & 2612,4 & 2975,8 & 3165,9 & 3428,9 & 3563,4 & 3560,4 & 3655,1 \\
\hline & $\begin{array}{l}\text { Дефицит } \\
(-) \\
\text { Профицит } \\
(+)\end{array}$ & 15,0 & $-10,6$ & $-52,3$ & $-11,9$ & $-14,7$ & $-27,5$ & $-42,2$ & $-54,7$ & $-63,3$ & $-10,0$ \\
\hline
\end{tabular}

Исходя из результатов, полученных в табл. 8, установлено, что бюджеты муниципального уровня обоих государств за анализируемый период были разбалансированы. Однако если для Германии несбалансированность в большей части проявляется в профиците местных бюджетов, то для России характерно превышение расходов бюджета над его доходами (дефицит).

Следует отметить, что для целей настоящего исследования динамические ряды показателей местных бюджетов являются недостаточными, в связи с чем необходим анализ относительных значений. С этой целью определим ряд эквивалентных показателей, экономическая сущность и практика формирования которых, в соответствии с национальным законодательством обоих государств, идентична. Например, нормы права обеих стран содержат понятие «налоговые доходы». Под налоговыми доходами (Steuern und steuerähnliche Einnahmen) в Германии понимаются доходы, имеющие характер налога, при этом налогами являются платежи, образующие налоговую систему Германии и включающие в себя: общие налоги (налоги, поступления от которых разделяются между федерацией, землями и муниципалитетами), федеральные, земельные (региональные) и местные налоги ${ }^{12}$. В России налоговыми доходами являются доходы от предусмотренных законодательством РФ о налогах и сборах федеральных налогов и сборов, в том числе от налогов, предусмотренных специальными налоговыми режимами, региональных налогов, местных налогов и сборов, а также

${ }^{12}$ Lexikon zur öffentlichen Haushalts- und Finanzwirtschaft. Steuerarten. URL: https://www.haushaltssteuerung.de/ lexikon-steuerarten.html. пеней и штрафов по ним ${ }^{13}$. Таким образом, указанные категории абсолютно аналогично рассматриваются в национальном законодательстве обоих государств, поэтому для целей анализа принимаем их в качестве эквивалентов. Полный перечень таких показателей-эквивалентов местных бюджетов представлен в табл. 9.

Таблица 9

Набор эквивалентных показателей для оценки местных бюджетов Германии и России за 2007-2016 гr.

\begin{tabular}{|c|c|c|}
\hline $\begin{array}{c}\text { Условное } \\
\text { обозначение }\end{array}$ & Германия & Россия \\
\hline \multicolumn{3}{|c|}{ В части доходов бюджета } \\
\hline$Д_{1}$ & Налоговые доходы & $\begin{array}{l}\text { Налоговые } \\
\text { доходы }\end{array}$ \\
\hline$Д_{2}$ & Подоходный налог & НДФл \\
\hline$Д_{3}$ & Налог на землю & $\begin{array}{l}\text { Земельный } \\
\text { налог }\end{array}$ \\
\hline$Д_{4}$ & $\begin{array}{l}\text { Перечисления от } \\
\text { земель (регионов) }\end{array}$ & $\begin{array}{l}\text { Безвоз- } \\
\text { мездные } \\
\text { поступления }\end{array}$ \\
\hline$Д_{5}$ & $\begin{array}{l}\text { Перечисления от } \\
\text { земель (регионов) } \\
\text { общего назначения }\end{array}$ & $\begin{array}{l}\text { Дотации + } \\
\text { иные меж- } \\
\text { бюджетные } \\
\text { трансорерты }\end{array}$ \\
\hline$Д_{6}$ & $\begin{array}{l}\text { Перечисления от } \\
\text { земель (регионов) } \\
\text { целевого назна- } \\
\text { чения }\end{array}$ & $\begin{array}{l}\text { Субвенции + } \\
\text { субсидии }\end{array}$ \\
\hline$Д_{7}$ & $\begin{array}{l}\text { Доходы } \\
\text { имущественного } \\
\text { бюджета }\end{array}$ & $\begin{array}{l}\text { Неналоговые } \\
\text { доходы }\end{array}$ \\
\hline Д & $\begin{array}{l}\text { Итого доходы } \\
\text { административного } \\
\text { иимущественного } \\
\text { бюджета }\end{array}$ & $\begin{array}{l}\text { Итого } \\
\text { доходы }\end{array}$ \\
\hline
\end{tabular}

${ }^{13}$ Бюджетный кодекс РФ [Электронный ресурс] : федер. закон от 31 июля 1998 г. № 145-Ф3 // СПС «КонсультантПлюс». 
Окончание табл. 9

\begin{tabular}{|c|l|l|}
\hline $\begin{array}{c}\text { Условное } \\
\text { обозначение }\end{array}$ & \multicolumn{1}{|c|}{ Германия } & \multicolumn{1}{|c|}{ Россия } \\
\hline \multicolumn{2}{|c|}{ В части расходов бюджета } \\
\hline$P_{1}$ & $\begin{array}{l}\text { Расходы на } \\
\text { персонал }\end{array}$ & Управление \\
\hline$P_{2}$ & $\begin{array}{l}\text { Расходы на соци- } \\
\text { альные услуги }\end{array}$ & $\begin{array}{l}\text { Социальная } \\
\text { политика }\end{array}$ \\
\hline$P$ & $\begin{array}{l}\text { Итого расходы } \\
\text { административного } \\
\text { иимущественного } \\
\text { бюджета }\end{array}$ & $\begin{array}{l}\text { Итого } \\
\text { расходы }\end{array}$ \\
\hline
\end{tabular}

Указанные показатели-эквиваленты приведем к сопоставимому виду путем использования относительных значений, отражающих долю (удельный вес) отдельного показателя в общей совокупности.

Так, в части доходов бюджета следует использовать фрормулу (1), а в части расходов - формулу (2):

$$
d_{Д_{i}}=\frac{Д_{i}}{Д} \cdot 100 \% \text {, }
$$

где Д (при $i=1-7)-$ соответствующий показатель доходов бюджета; Д - общая сумма доходов бюджета.

$$
d_{P_{i}}=\frac{P_{i}}{P} \cdot 100 \%,
$$

где $P_{i}($ при $i=1-2)-$ соответствующий показатель расходов бюджета; $P$ - общая сумма расходов бюджета.

Кроме того, логичным видится и рассмотрение среднего значения за весь десятилетний период таких относительных показателей доходов (расходов) в общей совокупности.

Подобные показатели позволяют выявить структурные изменения доходов, расходов местных бюджетов в условиях территориальной трансформации местного самоуправления Германии и России.

На основе данных табл. 4-7 с помощью программного продукта Microsoft Excel произведены расчеты относительных показателей-эквивалентов (табл. 10).

Таблица 10

Удельный вес отдельных показателей доходов (расходов) в общем объеме доходов (расходов)

\begin{tabular}{|c|c|c|c|c|c|c|c|c|c|c|c|c|}
\hline \multicolumn{2}{|c|}{ Показатель } & 2007 & 2008 & 2009 & 2010 & 2011 & 2012 & 2013 & 2014 & 2015 & 2016 & \multirow{3}{*}{$\begin{array}{r}\text { Среднее } \\
\text { значение }\end{array}$} \\
\hline \multicolumn{12}{|c|}{ В части доходов бюджета } & \\
\hline \multirow{2}{*}{$d_{A_{1}}$} & Германия & 38,95 & 39,98 & 36,42 & 36,43 & 37,91 & 39,08 & 38,59 & 38,52 & 38,70 & 38,40 & \\
\hline & Россия & 29,74 & 29,87 & 30,14 & 31,02 & 29,68 & 29,82 & 30,79 & 27,63 & 28,58 & 28,90 & 29,62 \\
\hline \multirow{2}{*}{$d_{A_{2}}$} & Германия & 13,49 & 14,67 & 13,88 & 13,11 & 13,36 & 14,10 & 14,30 & 14,68 & 14,83 & 14,34 & 14,08 \\
\hline & Россия & 19,95 & 20,49 & 20,71 & 20,20 & 19,71 & 20,92 & 21,53 & 17,55 & 17,65 & 18,12 & 19,68 \\
\hline \multirow{2}{*}{$d_{A_{3}}$} & Германия & 5,54 & 5,38 & 5,62 & 5,70 & 5,59 & 5,58 & 5,57 & 5,47 & 5,39 & 5,27 & 5,51 \\
\hline & Россия & 3,28 & 3,06 & 3,70 & 3,94 & 3,62 & 3,98 & 4,07 & 4,43 & 4,68 & 4,29 & 3,90 \\
\hline \multirow{2}{*}{$d_{A_{4}}$} & Германия & 28,93 & 29,67 & 31,38 & 30,62 & 30,74 & 31,56 & 32,61 & 33,33 & 34,14 & 35,70 & 31,87 \\
\hline & Россия & 57,96 & 58,58 & 59,66 & 59,24 & 60,73 & 61,77 & 61,09 & 63,78 & 63,37 & 63,35 & 60,95 \\
\hline \multirow{2}{*}{$d_{A_{5}}$} & Германия & 19,21 & 19,93 & 20,84 & 19,67 & 19,28 & 19,52 & 19,87 & 20,35 & 19,58 & 19,65 & 19,79 \\
\hline & Россия & 15,55 & 18,34 & 17,73 & 17,62 & 18,90 & 14,43 & 13,55 & 12,18 & 12,89 & 13,23 & 15,44 \\
\hline \multirow{2}{*}{$d_{A_{6}}$} & Германия & 9,72 & 9,74 & 10,54 & 10,95 & 11,46 & 12,05 & 12,74 & 12,98 & 14,56 & 16,05 & 12,08 \\
\hline & Россия & 42,41 & 40,23 & 41,93 & 41,62 & 41,83 & 47,34 & 47,54 & 51,61 & 50,48 & 50,12 & 45,51 \\
\hline \multirow{2}{*}{$d_{A_{7}}$} & Германия & 9,55 & 8,78 & 9,25 & 10,21 & 9,51 & 7,84 & 7,63 & 7,41 & 7,30 & 6,68 & 8,41 \\
\hline & Россия & 12,30 & 11,55 & 10,20 & 9,73 & 9,42 & 8,41 & 8,12 & 8,59 & 7,98 & 7,61 & 9,39 \\
\hline \multicolumn{13}{|c|}{ В части расходов бюджета } \\
\hline \multirow{2}{*}{$d P_{1}$} & Германия & 25,12 & 25,24 & 24,92 & 24,74 & 25,15 & 25,71 & 25,46 & 25,52 & 25,10 & 24,73 & 25,17 \\
\hline & Россия & 9,03 & 8,80 & 8,75 & 8,91 & 8,50 & 9,02 & 8,96 & 9,01 & 9,39 & 9,25 & 8,96 \\
\hline \multirow{2}{*}{$d P_{2}$} & Германия & 23,45 & 22,98 & 22,73 & 22,98 & 23,26 & 23,84 & 23,89 & 23,96 & 24,78 & 25,77 & 23,76 \\
\hline & Россия & 8,04 & 7,20 & 7,86 & 9,21 & 8,64 & 8,71 & 8,96 & 9,01 & 8,18 & 8,04 & 8,38 \\
\hline
\end{tabular}
местных бюджетов Германии и России за 2007-2016 гг., \% 
Как видно из табл. 10, удельный вес налоговых доходов местных бюджетов $\left(d_{z_{1}}\right)$ в Германии составляет чуть более $38 \%$, что на 8 \% больше, чем аналогичный показатель в России $(29,62$ \%). Однако если основным бюджетообразующим налогом местных бюджетов в России является НДФЛ, то в Германии - промысловый налог (Gewerbesteuer).

Таким образом, можно констатировать, что основную нагрузку при формировании местных бюджетов в Германии несут юридические лица, а в России - физические.

Доля поземельного налога Германии (в России - земельного налога) в объеме доходов местных бюджетов обоих государств примерно равна и составляет 4-5 \%, впрочем, как и доля имущественного бюджета (в России - неналоговые доходы бюджета), что соответствует 8-9 \% от общей величины доходов местных бюджетов. Указанное обстоятельство говорит о том, что муниципальные образования обеих стран получают примерно одинаковые доходы в относительном выражении от собственности, управления и продажи нефинансовых и финансовых активов (включая земельные ресурсы).

В России доходы местных бюджетов в среднем на 61 \% формируются за счет перечислений из вышестоящих бюджетов, в Германии - на $32 \%$, при этом ежегодно доля такого фринансирования в доходах местных бюджетов обоих государствах постоянно увеличивается. Тем не менее такие трансферты в Германии в большей части носят нецелевой характер, в России, напротив, субсидии и субвенции, предоставляемые на конкретные цели, составляют в среднем $45 \%$ доходов местных бюджетов.

С учетом относительной сопоставимости фринансовой статистики обеих стран в части расходов бюджета возможным для анализа стало сравнение лишь двух направлений расходов - расходов бюджета на управленческие и социальные нужды.

В расходной части бюджетов муниципальных образований Германии превалируют не только социально ориентированные расходы (финансирование безработных, малоимущих, инвалидов, престарелых и прочих незащищенных категорий граждан, предоставление социальной помощи в денежном и натуральном эквиваленте и другие выплаты), но и расходы на содержание персонала соответствующей муниципальной администрации. Каждое из рассмотренных направлений расходов в среднем составляет около 24-25 \% от общего объема расходов местных бюджетов Герма- нии. В России указанные разделы бюджетной классификации составляют в среднем чуть более 8 \% от расходов бюджетов муниципальных образований.

Используя результаты анализа изменения территориальной организации местного самоуправления и показателей местных бюджетов Германии и России, также можно сделать ряд выводов.

В Германии за анализируемый период на фоне сокращения числа муниципалитетов в расчете на 1 млн чел. и на 1 тыс. км² наблюдаются следующие тенденции в структуре местных бюджетов:

- незначительное снижение удельного веса налоговых доходов в период 20092011 гг., вызванное уменьшением доли по подоходному налогу и поземельному налогу, сигнализирует о снижении значимости местного поземельного налога в структуре бюджетов муниципалитетов, что говорит о необходимости усиления администрирования последнего;

- увеличение доли безвозмездных поступлений от земель в доходах местных бюджетов, обусловленное расширением целевых трансфрертов, свидетельствует о снижении финансовой самостоятельности муниципалитетов в части конкретных мероприятий;

- поступательное сокращение доли имущественного бюджета в структуре доходов местных бюджетов Германии характеризует процесс неэффрективного использования имущества, находящегося в муниципальной собственности;

- доля расходов на управление остается неизменной и колеблется в пределах сотых процентных пунктов, а удельный вес расходов на социальные нужды постоянно увеличивается.

В России в условиях уплотнения муниципалитетов по численности, но относительной стабильности в распределении муниципалитетов по территории проявляются несколько иные ориентиры в структуре местных бюджетов:

- снижение доли налоговых доходов в период 2014-2016 гг., обусловленное последствиями финансового кризиса 2014 г., повторяет тенденцию сокращения удельного веса налога на доходы физических лиц и подтверждает тезис о значительной зависимости доходов местных бюджетов от НДФЛ;

- увеличение удельного веса земельного налога в структуре бюджетов муниципальных образований следует расценивать как положительное явление, свидетельствующее о заинтересованности местных органов 
власти в увеличении поступлений от местных налогов;

- наращивание доли безвозмездных поступлений в структуре доходов местных бюджетов, вызванное увеличением субсидий и субвенций, подтверждает тенденцию наращивания программно-целевого метода при решении вопросов локального характера;

- при незначительном изменении доли расходов на муниципальное управление удельный вес расходов на социальную политику имеет тенденцию к постепенному снижению.

Таким образом, по результатам проведенного исследования можно сделать вывод, что выдвинутая выше гипотеза подтвердилась лишь частично. С одной стороны, изменения в территориальной организации местного самоуправления, безусловно, отразились на динамике, структуре, сбалансированности бюджетов муниципалитетов обеих стран. С другой стороны, произведенные расчеты и вычисления не позволили выявить степень такого влияния, поскольку не использовался корреляционный анализ.

Итак, можно утверждать, что российская и немецкая практика организации, трансформации местного самоуправления, а также функционирования местных бюджетов имеет отдельные принципиальные сходства и существенные различия. Тем не менее обе страны постоянно совершенствуют, развивают указанную сфреру общественной жизни с учетом изменений и вызовов, происходящих как внутри страны, так и во всем мире. Как показал анализ, под влиянием процессов глобализации и интеграции особенности и различия местного самоуправления и фи- нансовых основ его организации постепенно трансформируются и сглаживаются. Поиск оптимальной модели эфффективного местного самоуправления и муниципального бюджета многими государствами, в том числе и Россией, продолжается.

И, наконец, последнее. Проведенное исследование не раскрывает все особенности территориальной организации местного самоуправления, его реформирования и функционирования местных бюджетов Германии и России. Для полной характеристики данных вопросов следует оценить кредитоспособность, долговую нагрузку бюджетов муниципальных образований, выявить степень влияния территориальных изменений на основные параметры местных бюджетов. Кроме того, финансовая отчетность общественных фринансов Германии содержит значительное количество показателей, рассчитанных на душу населения, например доходы, расходы, дефицит на душу населения и т. д. Указанный подход может быть полезен и для анализа текущего состояния, а также оценки перспектив развития местных бюджетов Российской Федерации, поскольку такие показатели являются наиболее содержательными и позволяют осуществлять сравнение во времени и пространстве. В связи с этим интересным и полезным может стать исследование показателей местного бюджета конкретных муниципальных образований Германии и России - эквивалентов (или аналогов) территориальной организации, имеющих равную численность населения. Все это может стать предметом дальнейших изысканий, обсуждений и дискуссий в данной предметной области.

\section{СПИСОК ИСПОЛЬЗОВАННОЙ ЛИТЕРАТУРЫ}

1. Колодина Е. А. Новые реалии в развитии местного самоуправления / Е. А. Колодина // Публичное управление и территориальное развитие: новые тенденции и перспективы : материалы ежегод. междунар. науч.-практ. конф., Иркутск, 26-27 мая 2016 г. - Иркутск : Изд-во БГУ, 2016. - С. 11-23.

2. Леонов С. Н. Проблемные результаты и перспективы реформы местного самоуправления в России / С. Н. Леонов / / Пространственная экономика. - 2017. - № 3 (51). - C. 107-132. - DOI: 10.14530/ se.2017.3.107-132.

3. Лексин В. Н. Что происходит с местным самоуправлением в России? / В. Н. Лексин / / Федерализм. 2016. - № 1 (81). - С. 65-76.

4. Бабун Р. В. Местное самоуправление России на новом этапе муниципального строительства / Р. В. Бабун / / ЭКО. - 2017. — № 3 (513). - С. 60-77.

5. Ворошилов Н. В. Муниципально-территориальное устройство в России: адаптация к разнообразию / Н. В. Ворошилов / / Вопросы территориального развития. - 2017. - № 2 (37). - С. 1-15.

6. Сумская Т. В. Методические основы анализа региональных и местных бюджетов / Т. В. Сумская // ИНТЕРЭКСПО ГЕО-СИБИРЬ. - 2017. - Т. 3, № 1. - С. 85-91.

7. Киреенко А. П. Возможности структурных изменений в муниципальном бюджетном секторе / А. П. Киреенко, Т. В. Сорокина // Известия Иркутской государственной экономической академии. - 2012. № 5 (85). - C. 19-23.

8. Файберг Т. В. Проблемы и перспективы налоговых доходов в РФ / Т. В. Файберг / / Налоги и финансовое право. - 2015. - № 10. - С. 141-148.

9. Дементьев Д. В. Бюджетные полномочия и возможности муниципальных образований / Д. В. Дементьев / / Финансы и кредит. - 2017. - T. 23, № 17 (737). - C. 974-989. — DOI: 10.24891 /fс.23.17.974. 
10. Циммерманн X. Муниципальные финансы : [Введ. в науч. анализ финансовой деятельности местных органов власти] : учебник : пер. с нем. / Х. Циммерманн. - М. : Дело и Сервис, 2003. - 352 с.

11. Маркварт Э. Организация местного самоуправления в Германии и применимость немецкого опыта к российским реалиям / Э. Маркварт / / Контуры глобальных трансформаций: политика, экономика, право. 2011. - T. 4, № 2. - С. 25-36.

12. Маркварт Э. Территориальное реформирование местного самоуправления в Германии и России на современном этапе / Э. Маркварт, Й. Францке / / Пространственная экономика. — 2017. — № 3. - С. 4061. - DOI: $10.14530 /$ se.2017.3.040-061.

13. Бухвальд Е. М. Европейская Хартия местного самоуправления и зарубежный опыт в муниципальной реформе в России / Е. М. Бухвальд / / Вестник Института экономики Российской академии наук. - 2014. № 2. - C. 97-109.

14. Бухвальд Е. М. Европейская Хартия местного самоуправления и зарубежный опыт в муниципальной реформе в России (статья 2) / Е. М. Бухвальд / / Вестник Института экономики Российской академии наук. 2016. - № 5. - C. 25-42.

15. Уксусов В. В. Финансово-правовое положение муниципальных образований в России и Германии: аспекты сравнительно-правового анализа / В. В. Уксусов / / Вестник Университета имени О. Е. Кутафина. 2017. — № 8. - С. 185-194.

16. Ильиных А. В. Городской округ с внутригородским делением и внутригородские районы: особенности создания и первые итоги существования (опыт Челябинска) / А. В. Ильиных / / Конституционное и муниципальное право. - 2016. - № 7. - С. 67-70.

\section{REFERENCES}

1. Kolodina E. A. New Realities in the Development of Local Government. Publichnoe upravlenie i territorial' noe razvitie: novye tendentsii i perspektivy. Materialy ezhegodnoi mezhdunarodnoinauchno-prakticheskoi konferentsii, Irkutsk, 26-27 maya 2016 g. [Public Government and Territorial Development: new trends and prospects. Materials of Annual International Scientific Conference, Irkutsk, May 26-27, 2016]. Irkutsk, Baikal State University Publ., 2016, pp. 11-23. (In Russian).

2. Leonov S. N. Problematic Results and Perspectives of the Local Self-Government Reform in Russia. Prostranstvennaya ekonomika =Spatial Economics, 2017, no. 3 (51), pp. 107-132. DOI: 10.14530/se.2017.3.107132. (In Russian).

3. Leksin V. N. What is Going on with the Local Self-Government in Russia? Federalizm = Federalism, 2016, no. 1 (81), pp. 65-76. (In Russian).

4. Babun R. V. Local Government in Russia at the New Stage of Municipal Construction. EKO =ECO, 2017, no. 3 (513), pp. 60-77. (In Russian).

5. Voroshilov N. V. Municipal-Territorial System in Russia: Adaptation to Diversity. Voprosy territorial'nogo razvitiya = Territorial development issues, 2017, no. 2 (37), pp. 1-15. (In Russian).

6. Sumskaya T. V. Methodical Approach of Analysis of Regional and Local Budgets. INTEREKSPO GEO-SIBIR" $=$ Interexpo GEO-Siberia, 2017, vol. 3, no. 1, pp. 85-91. (In Russian).

7. Kireenko A. P., Sorokina T. V. Possibilities of Structural Changes in Municipal Budgetary Sector. Izvestiya Irkutskoi gosudarstvennoi ekonomicheskoi akademii = Izvestiya of Irkutsk State Economics Academy, 2012, no. 5 (85), pp. 19-23. (In Russian).

8. Faiberg T. V. Issues and Prospects of Tax Receipts in the Russian Federation. Nalogi i finansovoe pravo $=$ Tax and Financial Law, 2015, no. 10, pp. 141-148. (In Russian).

9. Dementev D. V. Budget Authorities and Capabilities of Municipalities. Finansy $i$ kredit = Finance and credit, 2017, vol. 23, no. 17 (737), pp. 974-989. DOl: 10.24891/fc.23.17.974. (In Russian).

10. Zimmermann H. Kommunalfinanzen. Eine Einf hrung in die finanzwissenschaftliche Analyse der kommunalen Finanzwirtschaft. Baden-Baden, Nomos Verlagsgesellschaft, 1999. 325 S. (Russ. ed.: Zimmermann H. Munitsipal'nye finansy. Vvedenie $v$ nauchnyi analiz finansovoi deyatel' nosti mestnykh organov vlasti. Moscow, Delo i Servis Publ., 2003. 352 p.).

11. Markvart E. Local Governance Organization in Germany and Application of German Experience in Russia. Kontury global'nykh transformatsii: politika, ekonomika, pravo= Outlines of Global Transformations: politics, economics, law, 2011, vol. 4, no. 2, pp. 25-36. (In Russian).

12. Markvart E., Frantske I. Territorial Realignment of Local Government in Germany and the Russian Federation in the Modern Period. Prostranstvennaya ekonomika =Spatial Economics, 2017, no. 3, pp. 40-61. DOI: 10.14530/ se.2017.3.040-061. (In Russian).

13. Bukhvald E. M. European Charter of Local Government and Foreign Experience in the Russian Municipal Reform. Vestnik Instituta ekonomiki Rossiiskoi akademii nauk = The Bulletin of the Institute of Economics of the Russian Academy of Sciences, 2014, no. 2, pp. 97-109. (In Russian).

14. Bukhvald E. M. The European Charter of Local Self-Government and Foreign Experience in Municipal Reform in Russia (paper 2). Vestnik Instituta ekonomiki Rossiiskoi akademii nauk = The Bulletin of the Institute of Economics of the Russian Academy of Sciences, 2016, no. 5, pp. 25-42. (In Russian).

15. Uksusov V. V. Financial and Legal Status of Local Authorities in Russia and Germany: the Aspects of Comparative Legal Analysis. Vestnik Universiteta imeni O. E. Kutafina = Courier of the Kutafin Moscow State Law University, 2017, no. 8, pp. 185-194. (In Russian).

16. Ilyinykh A. V. City District with Intra-City Division and Intra-City Areas: Features of Creation and First Results of Existence (Chelyabinsk Experience). Konstitutsionnoe i munitsipal' noe pravo = Constitutional and Municipal Law, 2016, no. 7, pp. 67-70. (In Russian). 


\section{Информация об авторе}

Кривоносова Наталья Яковлевна - кандидат экономических наук, доцент, кафедра финансов, кредита и бухгалтерского учета, Читинский институт (филиал) Байкальского государственного университета, 672000, г. Чита, ул. Анохина, 56, e-mail: krivonos_nat_ja@mail.ru.

\section{Для цитирования}

Кривоносова Н. Я. Организация местного самоуправления и состояние местных бюджетов Германии и России: сравнительный анализ / Н. Я. Кривоносова // Известия Байкальского государственного университета. - 2018. - Т. 28, № 2. - С. 208-222. DOI: $10.17150 / 2500-2759.2018 .28(2) .208-222$.

\section{Author}

Natalia Ya. Krivonosova - Ph.D. in Economics, Associate Professor, Department of Finance, Credit and Accounting, Chita Institute (Branch) of Baikal State University, 56 Anohin St., 672000, Chita, the Russian Federation, e-mail: krivonos_nat_ja@mail.ru.

\section{For citation}

Krivonosova N. Ya. Organization of Local Government and the State of Local Budgets of Germany and the Russian Federation: Comparative Analysis. Izvestiya Baykal'skogo gosudarstvennogo universiteta $=$ Bulletin of Baikal State University, 2018, vol. 28 , no. 2 , pp. 208-222. DOI: $10.17150 / 2500-$ 2759.2018.28(2).208-222. (In Russian). 